This item was submitted to Loughborough's Research Repository by the author.

Items in Figshare are protected by copyright, with all rights reserved, unless otherwise indicated.

\title{
The question of the human in the anthropocene debate
}

\section{PLEASE CITE THE PUBLISHED VERSION}

http://dx.doi.org/10.1177/1368431016651874

\section{PUBLISHER}

SAGE (@ the author)

\section{VERSION}

AM (Accepted Manuscript)

\section{PUBLISHER STATEMENT}

This work is made available according to the conditions of the Creative Commons Attribution-NonCommercialNoDerivatives 4.0 International (CC BY-NC-ND 4.0) licence. Full details of this licence are available at: https://creativecommons.org/licenses/by-nc-nd/4.0/

\section{LICENCE}

CC BY-NC-ND 4.0

\section{REPOSITORY RECORD}

Chernilo, Daniel. 2016. "The Question of the Human in the Anthropocene Debate”. Loughborough University. https://hdl.handle.net/2134/21428. 


\title{
The question of the human in the Anthropocene debate \\ (forthcoming in European Journal of Social Theory)
}

\author{
Daniel Chernilo*
}

\begin{abstract}
The Anthropocene debate is among the ambitious scientific programmes of the past 15 or 20 years. Its main arguments is that, from a geological point of view, humans are to be seen as a major force of nature so that our current geological epoch is depicted as dominated by human activity. The Anthropocene has slowly become a contemporary meta-narrative that seeks to make sense of the 'earth-system' as a whole, and one whose vision of the future is dystopian rather than progressive: as the exploitation of the planet's natural resources has reached tipping point, the very prospects of the continuity of human life are being questioned. My goal in this article is to explore the implicit notions of the human - indeed of the anthropos - that are being mobilised in the Anthropocene debate. I will proceed in two steps: first, I shall spell out the main the main arguments of the Anthropocene debate with a particular focus on trying to unpack its implicit ideas of the human. Secondly, I use of my approach to philosophical sociology to highlight some of the limitations and contradictions of the ideas of agency, reflexivity and responsibility that underpin the Anthropocene debate.
\end{abstract}

\footnotetext{
* Reader in Social and Political Though, Loughborough University. D.Chernilo@lboro.ac.uk. This paper is part of the project Research Cluster Millennium: "Nucleus Models of Crises" (NS 130017)
} 
The main thrust of the arguments on the Anthropocene that are now common currency in various disciplines in the natural sciences is that, from a geological point of view, humans are to be seen as a major force of nature. The Anthropocene is defined as a new 'geological' epoch that is 'dominated by human activity' (Zalasiewicz et al 2008: 4, my italics): humans are agents with the demonstrated ability to alter fundamentally the 'normal' cycles of nature. The Anthropocene debate has only emerged in the past 15 years or so and it has arrived in the social sciences and humanities only recently. If geographers seem to have been quicker to react to its call, this may well have to do with the fact that understanding the interactions between social and natural environments is built into the way they conceptualise the natural and the social worlds. ${ }^{1}$

The Anthropocene ranks among the most ambitious scientific programmes of the past 15 or 20 years (Maslin and Lewis 2015) and it is tempting to treat it as a new meta-narrative for the $21^{\text {st }}$ century. It is effectively an all-encompassing framework that seeks to make sense of the 'earthsystem' as a whole: it delineates the planer's natural history and turns it into a new geological period, it specifies the particular influence of human action in the emergence of that epoch, and it accounts for the relationships between the 'scientific' and the 'political' implications of these transformations (Arias-Maldonado 2015). Yet the vision of the future that the Anthropocene portrays is fundamentally dystopian as it is based on the assumption that the exploitation of the planet's natural resources is reaching, or has already reached, tipping point so that the very prospects of the continuity of human life are to be questioned. A futurology of crises is central to the cry for political action of most modern meta-narratives: in this case, the direct connection to the politics of global warming, and environmental issues more broadly, allows the scientific findings of the Anthropocene to be used readily in wider public debates. Indeed, the very fact that the Anthropocene may be seen as a dystopian meta-narrative gives an ironic twist to Jean-Francois Lyotard's (1984) original critique of modern meta-narratives: with the decline of the idea of progress, the only metanarratives that do survive are those that build on the limitations and shortcomings of modernity itself. ${ }^{2}$

An overview of the central tenets of the Anthropocene shows at least three different angles from which its rise and main features as a scientific narrative have been evaluated in the humanities and social sciences. The first can be connected with Bruno Latour's $(1993,2013)$ version of actor-network theory: the Anthropocene challenges conventional understandings of culture, society and nature as self-contained ontological domains. If the Anthropocene can empirically demonstrate that humans have altered those physical properties of our planet whose origin is non-human, then the very notion of different ontological domains seems to require serious revisiting. ${ }^{3}$ A second line of argument comes from the acceptance that, notwithstanding its possible philosophical, sociological or ideological shortcomings, the Anthropocene thesis ought to be taken seriously because it is based on solid empirical evidence. Dipesh Chakrabaty $(2009,2012)$, for instance, humbly admits that, while many of us are unable able to assess independently, let alone understand fully, the empirical information that is being discussed in support of the Anthropocene, the fact that it has become so consensual in such a short period of time needs to be taken as indication of its seriousness. To be sure, those on the more humanistic side of the two cultures have been quick to emphasize that social and cultural practices ultimately underpin all discoveries in the natural sciences (Lövbrand et al 2015). Yet Chakrabaty's call is not altogether sound because, other than agreeing on the fact that humans have triggered changes on the earth's various natural environments, and that these changes do have an impact on the future prospects of human 
life, there is little consensus as to what exactly the Anthropocene is, how and when exactly it started and, what its main empirical indicators are. ${ }^{4}$ A third line of argument is offered by those with a more openly 'political' interest and focuses on how the Anthropocene is another expression of predatory nature of modern capitalism. Regardless of whether they accept the empirical evidence behind the idea of the Anthropocene, their claim is that this debate is another demonstration of the intrinsically predatory character of capitalism whose logic of continues to expand: capital's domination of labour and empires' dominations of colonies are both underpinned by the fundamentally exploitative dynamics of human action over nature (Malm and Hornborg 2014). The Anthropocene is seen as the most recent expression of the same perverse logic that has now 'colonised' all areas of human and natural life. ${ }^{5}$

These are all arguments that still require further discussion but they are the ones to which most attention has been paid so far. I should like my contribution to this special issue to focus on a different set of concerns. In the past few years, and under the banner of philosophical sociology, I have been arguing that we require a more thorough understanding of the - often implicit - ideas of the human, humanity, and even human nature that underpin both political and social-scientific debates (Chernilo 2014, 2017). The sociological purchase of looking at these implicit ideas of the human, I contend, lies in the fact that they are the ones giving content to normative ideas in society such as justice, solidarity and autonomy. A key argument of philosophical sociology is that way in which we discuss these ideas in society is based on how we conceive the anthropological features with which humans themselves define their shared membership to the human species. My goal in this article is to put this approach to work in order to explore the implicit notions of the human - in this case, the reductionist account of the anthropos - that underpins the Anthropocene debate.

I will proceed in two steps. First, the article will spell out the main arguments of the Anthropocene debate with a particular focus on trying to unpack its implicit ideas of the human. Secondly, it will explain the main features of my approach to philosophical sociology in order to show that the Anthropocene debate is based on too narrow an understanding of agency, reflexivity and responsibility as specifically human traits.

\section{Unpacking the Anthropocene}

A chemist by training, Nobel Prize winner Paul J. Crutzen published in Nature a one-page long article that was one of the first to offer the Anthropocene as a new scientific meta-narrative. His piece opens as follows:

For the past three centuries, the effects of humans on the global environment have escalated. Because of these anthropogenic emissions of carbon dioxide, global climate may depart significantly from natural behaviour for many millennia to come. It seems appropriate to assign the term 'Anthropocene' to the present, in many ways humandominated, geological epoch, supplementing the Holocene - the warm period of the 10-12 millennia (Crutzen 2002: 23)

This opening statement captures most of the key ideas of the Anthropocene debate remarkably well; hence, I would like to expand on some of its main presuppositions and implications. It gives us a good sense of what is at stake in the Anthropocene debate and, crucially for my purposes, it will illuminate on its implicit ideas of the human. 
1. The anthropocentric argument. Scientists working in this field draw on a wide range of evidence to make then claim that humanity has become the most powerful of geological forces. Even if disagreement remains on how to account exactly for this impact, the key argument is that the aggregated effects of human action have already altered the normal behaviour of such natural cycles as average temperatures of air and water, the transformation and disappearance of self-contained habitats, the chemical composition of the atmospheric gasses and the oceans, etc. (Hamilton and Grinevald 2015, Lewis and Maslin 2015a, 2015b, Maslin and Lewis 2015, Steffen, et al 2007, 2015, Zalasiewicz et al 2008, 2015). Researchers then emphasize the need to speak about the 'planetary boundaries' of the 'earth-system': humans and nature are definitively joined together (Rockström et al 2009). The delineation of the Anthropocene as a novel geological epoch does not depend on the claim that human activities have left their mark on natural the environment. The idea of the Holocene, the geological period that preceded the Anthropocene, was already defined in order to account for the fact that homo sapiens had already left a huge imprint on their immediate habitats: from fire to the use of coal via agriculture and the domestication of animals. What marks the rise of the Anthropocene proper is the fact that current geological transformations are dominated by human action. It is the centrality of human action that allows them to speak about an earthsystem where the 'old' distinction between the natural and the social no longer holds. Put differently, there is a fundamentally anthropocentric core to the idea of the Anthropocene: it is another realisation, as it were, of how powerful human action actually is. In fact, the argument can be made that in the social sciences we are used to the idea that humans, being the social and cultural creatures that they are, have the ability to change, but never fully control, the structural contexts within which their actions take place. The Anthropocene may be said to amplify rather than to redefine radically this presupposition, as it focuses on the ways in which the aggregated behaviour of the human species as a whole reaches truly cosmological proportions: the structures that human are able to change under conditions of uncertainty include also those of the natural world. The aggregated effects of human action have grown so powerful that they have effectively modified, arguably for the first time in the globe's history, nearly all aspects of the earth's natural environments. Humans have become the major transformative agent of the earth's fundamental chemical processes and physical structures. ${ }^{7}$

2. The global argument. During the Holocene, the impact of human activities on the natural environment left a mark at local or regional levels, but it is only in the Anthropocene that these geological transformations become truly global: no part of the planet (land, water or air), nor indeed any human group, remains unaffected by the impact of human action on the environment. The only meaningful geographical unit for the Anthropocene is therefore the earth as a whole and, because of this, its only meaningful agent is humanity itself understood as a single species. The 'universalism' that underpins most arguments in the Anthropocene coheres on this dual notion that one planet equals one human species. Concerned as they are with the highly unequal distribution of burdens and benefits that marks the rise and development of most modern institutions - capitalism, the modern state, empires, etc. historians and social scientists are particularly troubled by the uncritical or even ideological appeal to 'universalism' that these arguments bring with them (see, for instance, Luke's contribution to this special issue). To my mind, it is true that the Anthropocene literature does not elaborate on this point clearly enough, but it is wrong to contend that a global or indeed universalistic is intrinsically unable to do so. Rather than abandoning a universalistic orientation, what we need is a much fuller account of it. ${ }^{8}$ I will come back to this point below. 
3. The temporality argument. There are two, very different, temporal units in the Anthropocene debate. In the quotation I used above, Crutzen opens with a reference to the 'past three centuries' that is rather conventional for modern historians and social scientists: this is of course the time-frame that allow us to speak about the increasingly relevant role of modern capitalism, state, industry and technology. But the quotation ends with a reference to '10-12 millennia' that refers to the kind of natural history that makes little sociological sense but is conventional in geography and geology. In fact, a key area of debate in the literature refers to how to account for the so-called 'great acceleration' of human-dominated activity on the environment that has taken place in the past 50 or 60 years (Steffen et al 2015). Once again, this is a unit of time that is perfectly manageable from the point of view of the humanities and social sciences and it coincides also with the systematic expansion modern industry and technology at a truly global scale (BRIC countries, the so-called Asian tigers, etc.). ${ }^{9}$ Most empirical indicators that are used in the Anthropocene debate do highlight the importance of this recent acceleration (for instance, population grown, water use, fertilizer consumption, lost of tropical and rain forests, or carbon dioxide in the atmosphere), but the counterclaim is that, from a geological point of view, a few decades is not a unit that is available to empirical observation, let alone theoretical elaboration (Hamilton 2015). The temporal scope that is required to quantify the long-term impact of our current interventions on the environment may require several millennia. The normative question that remains is whether the short-term benefits of instrumental actions have become increasingly, or even definitively, separated from what they expect to be their mostly negative long-term impacts.

4. The instrumental rationality argument. The kinds of human activity that are described in the literature as defining the Anthropocene point to the active processes of adaptation to and transformation of the natural environment: the constant development of new sources of energy and of new domestication techniques for food crops and animals; changes in humans' eating habits that, as they allowed for greater physical strength and enhanced mental capabilities, eventually triggered sustained periods of population growth; the exponential increase of extraction of fossil fuels such as coal, oil and gas, the systematic improvements in means of transports which, since the transformation of navigation techniques in the 15th and $16^{\text {th }}$ centuries, have allowed for continuous trans-continental exchanges of peoples, commodities, cultural goods, and even bacteria (Steffen et al 2007, Zalasiewicz et al 2015). There are two technological innovations that are highlighted the most in the literature: the industrial technologies that were developed in the middle of the $19^{\text {th }}$ century and the increased availability of nuclear energy since the middle of the $20^{\text {th }}$ (Lewis and Maslin 2015a, 2015b). In all cases, the Anthropocene narrative is dominated by the ways in which technological innovations have allowed humans ever-greater success in their attempts at adapting the natural world to their own ever-growing needs: this is a general argument about the instrumental mastery of the world. Given the centrality of technological success in the Anthropocene literature, instrumental rationality has effectively become equated, indeed reduced, with human rationality. ${ }^{10}$

5. The normative argument. There is no question that the Anthropocene as a field of scientific research is explicitly motivated by extra-scientific considerations regarding the future prospects of human life in the planet. Indeed, a key ethical motif in the whole Anthropocene debate is the fact that we ought to consider the prospects of human self-annihilation as part of our political and scientific responsibilities. Sustainability becomes a visible issue, and 
eventually a problem, because human action undermines the natural sources on which human life reproduces itself. Stewardship has become a term of choice to highlight the enhanced ethical command for humans to look after the planet (Arias-Maldonado 2015, Steffen et al 2015). The Anthropocene makes good of its name, however, as it does not really raise what is arguably the broader question of the viability of the earth itself: it remains a wholly anthropocentric perspective. Also, it is worth remembering that ethical reflections on the impact of human activities on the environment are arguably a universal constant of the human mind and societies: all ancient civilisations and world religions have shown an explicit concern for the ways in which their actions may have a (negative) impact on the earth's response to their own adaptation to the environment. Early religious, cosmological, and philosophical motifs remind us of the existential anxiety of collective survival vis-à-vis a natural environment that remains unpredictable (Blumenberg 2015, Jonas 1963, Voegelin 1962).

From what we have said so far we can define the Anthropocene as an attempt to understand the development of an all-encompassing earth-system whose geological qualities are dominated by the long-term, aggregated and unintended effects of human action at a global scale. To my mind, however, there is a fundamental tension underpinning the idea of the Anthropocene. On the one hand, as we have seen, the Anthropocene remains the most anthropocentric of scientific concepts: it 'demonstrates', as it were, that the causal powers of human action have reached such extraordinary proportions that they no longer stop at the creation of fantastic social and cultural artefacts whose origin can ultimately be traced back to human actions; instead, they affect, without however controlling in full, nature herself. The fundamentally anthropocentric motive of the Anthropocene is the unrelenting and selfpropelling trajectory that started several millennia ago with the early domestication of animals and the invention of agriculture. It then moved on to endless experiences of colonization over other humans (imperialism comes in all shapes and sizes) and three centuries or so ago, it reached new heights as it completed the colonization processes of nature herself. Finally, in the past few decades medical and genetic developments have allowed also for the 'internal' colonisation of our own bodies. The aggregated powers of human action and the allpervasiveness of instrumental rationality become two central markers of the idea of the human in the Anthropocene. On the other hand, this same anthropocentric argument that emphasizes the causal might of human action points, normatively, in the opposite direction: the unintended consequences of instrumental human action and their destructive potential. Indeed, whilst the arguments about technology and instrumental rationality highlight our human ability to transform our immediate surroundings, its normative tone makes clear the extent to which the biochemical and atmospheric transformations that humans have triggered over the past centuries now endanger the very subsistence of our species (and, by implication, of all the species with which we share the earth and of the earth).

The description of our current geological era as the Anthropocene reflects the fundamental human arrogance of anthropocentrism: 'the anthropos' always finds a reason to put itself centre stage and, as it does so, it discloses the 'real' nature of us humans: our condition as the earth's greatest predator. The very features that demonstrate our supreme potential as a species - instrumental rationality and the power of technology - become also the cause of the gravest of normative challenges: if humans carry on succeeding at what they do best, they will eventually destroy themselves. Put differently, the Anthropocene thesis is sustained on the notion that humans are intrinsically unable to abandon their self-centred perspective (even in 
those moments of crises that threaten our collective self-destruction): anthropocentrism is the alpha and omega of who we are as a species.

This is what we may call the anthropocentric paradox that the Anthropocene debate brings into full view: the same human ability to alter the earth's natural environment, the fantastic might of our human powers, is also the cause of the normative defeatism that sees an ecological catastrophe as inevitable: humans have proved so successful at changing nature that they fall victim of their own success. The ultimate normative implication of our instrumental success in transforming the world is the very real prospect of human-induced self-annihilation.

\section{Philosophical Sociology}

The idea of philosophical sociology that I have been developing over the past few years focuses on the need to articulate those, mostly implicit, conceptions of the human, humanity and human nature that are central to our understanding of social life (Chernilo 2014, 2017). I call it philosophical sociology in order to highlight two main arguments. First, the need to bring together philosophical questions about who we are as human beings and sociological ones about the nature of social life itself: good sociological questions that look at the most general features of social life are, in the last instance, also philosophical ones that speak about who we are as human beings. Second, the notion of philosophical sociology allows me to draw attention to the early- $20^{\text {th }}$ century tradition of philosophical anthropology. Originally associated with the names of Max Scheler (2009) and Ernst Cassirer (1977) in the 1920s and 1930s, philosophical anthropology was explicitly devoted to the development of a general understanding of 'what is a human being'. For my purposes, the most important intervention in this field comes from a short book by Karl Löwith (1993). First published in 1932, Löwith's Max Weber and Karl Marx starts by putting forward an argument that has since become familiar: Weber and Marx shared an interest in the rise and contemporary workings of modern capitalism and offered radically different interpretations of it. Their scientific originality, that is, the development novel sociologies, is apparent in how their historical and conceptual sophistication wholly transformed our study of capitalism and social life more generally. But Löwith also argues that their explicit sociologies are in fact underpinned by a common philosophical concern that is the ultimate motif of their work: what it means to be human under the alienating conditions of modern capitalism. Löwith contends that Weber and Marx were 'essentially sociologists, namely, philosophical sociologist (...because...) both provide Marx directly and Weber indirectly - a critical analysis of modern man within bourgeois society in terms of bourgeois-capitalist economy, based on the recognition that the "economy" has become human "destiny"' (Löwith 1993: 48, my italics). As philosophical anthropology continued to develop after World War II, the notion that emerged was that a dual scientific and philosophical approach to understanding the human results from, and must be preserved, because of the duality of the human condition itself: humans are bodies that are controlled by their urges, emotions and organic adaptation to the world and they are also conscious beings that are defined by their intellectual, aesthetic and indeed moral concerns (Gehlen 1988, Plessner 1970). A key motif of philosophical anthropology was the claim that human beings are fundamentally indeterminate with regards to organic adaptation and this is what makes social institutions and cultural practices essential to human life. ${ }^{11}$

At the same time, the question of anthropocentrism is anything but new in the history of social and political thought. If we look at developments since the end of World War II, much of its 
immediate philosophical debate touched on whether the anthropocentrism that allegedly underpinned the modern dreams of instrumental mastery were in fact to blame for the atrocities that were committed against human beings themselves. This theme plays an important role, for instance, in Adorno and Horkheimer's (1997) critique of instrumental rationality, but for our purposes here the most salient arguments are found in the so-called debate on humanism between Jean-Paul Sartre and Martin Heidegger. ${ }^{12}$ In his Existentialism Is a Humanism, which was first delivered as a lecture in Paris in October 1945, Sartre (2007) offered a defence of 'traditional' humanist values and of an egalitarian idea of freedom and individual autonomy on the grounds of anthropocentrism: 'man' is the measure of all things and the world humans inhabit is wholly of human making. Sartre also makes a great deal of the historical necessity of human progress as a process of reconciliation between the universal and the particular: '[e]verything happens to every man as if the entire human race were staring at him and measuring itself by what he does' (2007: 26, my italics). In his Letter on Humanism, that was originally drafted in 1946 partly as rejoinder to Sartre's argument, Heidegger (1993) made three counter-claims: (1) through its egalitarianism and universalism, anthropocentrism and humanism were themselves to blame for the war and its atrocities; (2) to the extent that our human existence has being reduced to our natural existence as a living species, humanism cannot be made a source of value, so we ought to worship higher forms of 'being'; (3) through their masterful command of language, a new elite of poets and thinkers were to restore human dignity by becoming self-appointed 'shepherd of being' (Heidegger 1993: 234). Much can and has been said about this debate: crucially, to my mind, Sartre's egalitarianism compares favourably with Heidegger's elitism. For our specific purposes in this piece, however, this debate is informative because it allows us to differentiate between two arguments.

There is a first, cognitive, proposition that challenges the notion that we can establish with precision what exactly are the powers that define our shared humanity as members of the same species. As argued eloquently by, for instance Lévi-Strauss (1970) and Foucault (1997), the modern obsession with defining the human in the singular - as apparent not least in modern ideas of human nature - remains a major epistemological obstacle in the way in which the humanities and social sciences pursue their intellectual tasks. An argument that was arguably first put forward by Gaston Bachelard (2002) in the last 1930s, the development of a genuine scientific approach requires humans to abandon their (naïve) anthropocentrism: modern science was only able to emerge as humans leave behind the narcissistic idea that they are at the centre of the universe. This motif informs various of the best-known critiques of anthropocentrism of the past few decades: an explicit focus on the human blocks from view the extent to which power (Foucault 1995), language (Derrida 2002), society (Luhmann 2012) and capitalism (Althusser 2003) are in fact autonomous ontological domains. But there is a second, normative, side of the argument: if anthropocentrism is now demonstrably a perspective that prevents humans from understanding the world as it actually is, then we must equally abandon humanism as its normative counterpart. If there is no such a thing as the human being in the singular, then all normative programmes that treat the human as source of value are themselves misguided. In fact, this is precisely what critics have argued is the main normative lesson of the World Wars: either humanism is too feeble a normative notion human rights or crimes against humanity were unable to prevent the commitment of atrocities - or humanism is itself to blame because, in modern times, the most horrific of crimes are always committed on its behalf (Sloterdijk 2009). The cognitive critique of anthropocentrism and the normative critique of humanism are of course closely interrelated but we should be able to keep them apart. As a programme that seeks to understand the relationships between 
preconceptions of the human and ideas of social life, philosophical sociology does not argue for a return to the anthropocentrism, but it does favour the reinvigoration of a humanist perspective. It is an invitation to reconsider the idea that social life itself is predicated on the fact that human beings are capable of such collective existence.

If we now go back to the anthropocentric paradox with which I concluded the first section of this paper, we can see that it is also apparent in the Anthropocene debate. Andreas Malm and Alf Hornborg (2014: 65), for instance, make the following argument:

climate change is denaturalised in one moment - relocated from the sphere of natural causes to that of human activities - only to be renaturalised in the next, when derived from an innate human trait, such as the ability to control fire. Not nature, but human nature - this is the Anthropocene displacement ${ }^{13}$

Interested as they are in the redefinition of the relationship between the natural and the human, Malm and Hornborg reject as reductionist Anthropocene ideas of human nature. They point in the right direction here because the 'displacement' carried out by the Anthropocene is incomplete: anthropocentrism comes back with a vengeance because we also require humans in order to understand nature herself. But to my mind their own narrow understanding of the human, as expressed in their flat rejection of universalism as species-talk, creates even greater problems. My first conclusion in this paper is that we need a broader idea of agency than Anthropocene scholars (and its critics!) allows for: whether we can have a general notion of agency without reflexivity is an open philosophical debate (Elder-Vass 2010), but what we cannot have is an idea of a human agent that lacks reflexivity.

If we follow Margaret Archer $(2000,2003)$, human reflexivity is central for the characterization of an autonomous agent. We can conceive passive social positions as devoid of reflexivity; yet, collective action requires the ability to turn these positions into specific projects (e.g. the difference between being a worker because of our age, qualification or family background and being a trade unionist who takes part in industrial action). This matters to us because, rather than rejecting the species-talk of the Anthropocene as one of its major limitations, I contend that it is the enhanced human ability of reflexive decentring that is central to our ability create and imagine new social forms and normative ideas: this is a general anthropological capability that we possess as a species. We have seen that, because in the Anthropocene debate human action is effectively equated to instrumental rationality, then there is no option but to contend that human reflexivity entails only strategic action. Here, the social sciences' reductionist account of the social as fields where power relations and strategic bargaining are allencompassing is being mirrored in the Anthropocene debate by an idea of reflexivity that is purely strategic vis-à-vis the aggregated outcome of human action. Mainstream social science contributes to the problem rather than to the solution of this difficulty. ${ }^{14}$

Yet most accounts of the development of those cognitive skills that are central to the rise of philosophy and science as a human enterprise do emphasise major acts of human de-centring. From the philosophy of language to our theories of to the observation of planetary orbits and gravitational forces, the 'Copernican revolution' that inaugurates modern science and philosophy speaks precisely of the human ability that, in order to be able to explain the cosmos and society, humans must not locate themselves at their centre (Blumenberg 1987, 2015). Seen in this light, the most fundamental feature of human reflexivity is that we can deploy a 
sense of self-transcendence so that we are able to look at the world from somebody else's point of view. We can thus conceive new social institutions, create rules that allow us to think and assess different social orders and, last but least, change, modify or remedy the results of our individual and collective actions (Arendt 1978, Parsons 1978). Our ability to conceptualise these features requires us to open up our conceptions of the human to dimensions that have been completely left out in the Anthropocene debate. It is my contention that there are at least seven of these basic anthropological skills and, as we put these ideas together a different concept of the human begins emerge: self-transcendence, adaptation, responsibility, language, moral evaluations, reflexivity and the reproduction of life. ${ }^{15}$ These anthropological traits define us as members of the same species and create the conditions for social life to unfold, without this common humanity itself being able to act directly on society. They are the basis from which ideas of justice, self, dignity and the good life emerge and are irreducible to material factors because their normative worth refers back to our conceptions of what is to be human. They are universal insofar as they include all individuals as members of the same human species and they are also socially differentiated in the ways in which humans actualise them. This turns a generic notion of 'species-being' into a more workable social-scientific concept. Seen in this light, humans are competitive, selfish and predatory - and this fits well the reductionist notion of the anthropos that we have seen underpins the Anthropocene debate but humans are also evaluative, cooperative and reflexive beings.

My second and last conclusion for this paper can be illustrated through a reading of Hans Jonas' Imperative of Responsibility (Jonas 1984). First published in 1979 and written in the context of the rise of green politics in Germany, there is much in Jonas' argument that preempts and is consistent with the Anthropocene debate: human life has fundamentally altered the ways in which nature reproduces itself, we are at tipping point vis-à-vis the extractive capacity over natural resources and the developments of modern science and technology of the past few centuries are key to challenges that are posed by these transformations. Jonas also elaborates on the temporality of his normative call in a way that speaks directly to some of the key motifs of the Anthropocene debate: humans are beings who have a moral duty towards the humans of the future: we have the collective responsibility of leaving them the planet in such a state that they will also be able to lead a life that is worth calling 'human'; that is a self-determining life.

But Jonas' (2001) wider intellectual project, philosophical biology, departs in at least one crucial respect from the Anthropocene debate: Jonas wholly rejects its anthropocentrism. Indeed, a critique of anthropocentrism is central to his philosophy: all living beings, all forms of organic life, are ends for themselves and not a mere resource for humans. His argument is that humans' organic constitution is something that they share with all other forms of life. As 'the first form of freedom', continuous existence defines the essential form of identity that constitutes life itself (Jonas 2001: 3). Life is an end in itself and this is a common denominator that humans and all living creatures have in common. Because they are alive and as long as they remain alive, all organisms look after themselves and pursue the maintenance of their existence as their own 'continuous achievement' (2001: 80). If this is the case, then human nature is not qualitatively different from any other type of organic life - however simple. Indeed even human 'sociality', which is reflected in the fact that the realization of some species' organic potentials requires the company of and association with others, is not specifically human. The realization of their organic potentials may well require for certain species to live within a collective environment, and this sociality remains something that 
organisms ought to do because it is in their nature: even as they have a natural impulse to sociality and their inner impulses are forcefully directed to sociality - as in the case of bees and ants - the source of these tendencies remain previous to it. What makes human life unique is precisely that it can decentre itself: it is able to stop making everything to cohere around its own immediate needs.

Jonas accepts that human beings are an object of concern for themselves because this is the way in which all forms of life organize themselves, but he rejects a conception of nature whose only value resides in its instrumental availability for human being: humans are an object of nature rather than their master. Humans are not the measure of all things but instead our particular species-centred perspective has the unique ability to understand the workings of nature - and in order to do so, it must de-centre itself. Jonas then turns this cognitive skill into a moral command: only humans can take responsibility for the rest of nature because they have the power to do so. It is 'the scope and kind' of human powers that 'determine' the type of responsibility humans have and this remains a responsibility that falls only on human shoulders (1984: 98, 128). Given the scale of technological innovations and environmental challenges that are a direct result of human intervention, this responsibility has dramatically intensified over the past century. Indeed, it has become a major social question of our times: under the current global circumstances, humans now have a responsibility towards the planet as a whole In addition to the philosophical redefinition of life and organic nature, Jonas argues therefore that there is a pragmatic urgency that makes environmental challenges relevant. Even if we fail to agree on such foundational questions as a common conception of the human, nature or life, these polemics are secondary to the practical and political demands of the world in which we live:

we find ourselves thrown back from the ever-open question, what man ought to be (the answer to which is changeable), to the first commandment tacitly always underlying it, but never before in need of enunciation: that he should be - indeed, as a human being (...) what now matters most is not to perpetuate or bring about a particular image of man but first of all to keep open the horizon of possibilities which in the case of man is given with the existence of the species as such and (...which...) will always offer a new chance to the human essence (1984: 139-40)

Jonas' imperative of responsibility commands that our actions ought to safeguard the possibility of continuous human habitation in the future. We have the duty to leave the planet in a state that is worthy of human habitation, a planet that will allow future human beings to lead a fulfilling human life. Formulated as a moral law, Jonas introduces his imperative of responsibility thus: 'there ought to be through all future time such a world fit for human habitation, and (...) it ought on all future time to be inhabited by a mankind worthy of the human name' (Jonas 1984: 10). We owe to future generations that they are able to conduct their human life as a self-legislating experience: traditional ideas of self-preservation need to be broadened in order to include an imperative that guarantees the future existence of human beings. The more we are concerned with the future of humanity, the better will humans look after nature itself in the present.

Jonas' position is not free of difficulties; not the least of which is that he favours an arrangement in which technocracy is preferred over democracy when it comes to making the right decisions on the environment. This is problematic because it curtails in the present the 
very principle of human self-legislation that he seeks to safeguard for the humanity of the future. In other words, whilst Jonas is aware of the dangers of reducing reflexivity to instrumental rationality - as it is apparent in the Anthropocene debate - his position does not pay equal attention to the reverse challenge: instrumental rationality is able to enhance and extend moral reflexivity itself.

All its scientific, philosophical and even political merits notwithstanding, the Anthropocene debate is built on a very narrow understanding of what a human being is and what human life consists of. It is based on an idea of the anthropos as a selfish being whose only drive is the constant satisfaction of its multifarious needs through an incessantly instrumental attitude towards everything and everyone that surrounds it. On the contrary, it has been my contention here that there is one aspect of the universalistic orientation of Jonas' ethical theory that remains central to our normative imagination: humans can be appealed to as moral agents. This is an appeal that builds on rather than stands in opposition to our human experiences as beings who reside in the natural world. If humans are genuinely to be seen as a geological force, then this is the case because they can realize that the consequences of their actions are to be felt beyond what is conventionally conceived as 'the foreseeable future'. But the human ability to think about its responsibility towards future generations is being curtailed rather than enhanced by the way in which proponents of the Anthropocene remain blind to, rather than build on, the acts human decentring and responsibility that are central to all critiques of anthropocentrism.

\section{References}

Adorno, T. and Horkheimer, M. (1997) Dialectic of enlightenment, London: Verso.

Althusser, L. (2003) 'The humanist controversy', in Althusser, L. The humanist controversy and other writings, London: Verso.

Archer, M. S (2000) Being human. The problem of agency, Cambridge: Cambridge University Press.

Archer, M. S (2003) Structure, agency and the internal conversation, Cambridge: Cambridge University Press.

Arendt, H. (1978) The life of the mind, New York: Hartcourt.

Arendt, H, (1998) The human condition, Chicago: The University of Chicago

Arias-Maldonado, M. (2015) 'Spelling the end of nature? Making sense of the Anthropocene', Telos 172: 83-102

Bachelard, G. (2002) The formation of the scientific mind, Manchester: Clinamen.

Beck, U. (1992) Risk society. Towards a new modernity, London: Sage.

Bell, D. (1974) The coming of post-industrial society, London: Heinemann. 
Blumenberg, H. (1987) The genesis of the Copernican world, Cambridge, Mass.: MIT Press.

Blumenberg, H. (2015) The laughter of the Thracian woman. A protohistory of theory, London: Bloomsbury.

Cassirer, E. (1977) An essay on man, New Heaven: Yale University Press.

Castells, M. (1996) The rise of the network society, Oxford: Blackwell

Certini, G. and Scalenghe, R. (2015) 'Is the Anthropocene really worthy of a formal geological definition?', The Anthropocene Review 2 (1): 77-80.

Chakrabaty, D. (2009) 'The climate of history: Four theses', Critical Inquiry (Winter): 197-222.

Chakrabaty, D. (2012) 'Postcolonial studies and the challenge of climate change', New Literary History 43 (1): 1-18.

Chernilo, D. (2013) The natural law foundations of modern social theory. A quest for universalism, Cambridge: Cambridge University Press,

Chernilo, D. (2014) 'The idea of philosophical sociology', British Journal of Sociology 65 (2): 338357.

Chernilo, D. (2015) 'Book Review: Bruno Latour. An enquiry into modes of existence: An anthropology of the moderns', European Journal of Social Theory 18 (3): 343-348.

Chernilo, D. (2017) Debating humanity. Towards a philosophical sociology, Cambridge: Cambridge University Press

Childe, V. G. (1962) Man makes himself, London: Mentor.

Clark, N. (2014) 'Geo-politics and the disaster of the Anthropocene', The Sociological Review 62 (1): 19-37.

Crutzen, P. (2002) 'Geology of mankind', Nature 415: 23.

Crutzen, P. and Steffen, W. (2003) 'How long have we been in the Anthropocene era?', Climatic Change 61: 251-7.

Derrida, J. (2002) Writing and difference, London: Routledge.

Durkin, K. (2014) The radical humanism of Erich Fromm, Basingstoke: Palgrave Macmillan.

Elder-Vass, D. (2010) The causal powers of social structures, Cambridge, Cambridge University Press.

Foucault, M. (1995) Discipline and punish, London: Vintage. 
Foucault, M. (1997) The order of things, London: Routledge.

Gehlen, A. (1988) Man. His nature and his place in the world, New York: Columbia University Press New.

Habermas, J. (1984) The theory of communicative action. Volume 1: Reason and the rationalization of society, London: Heinemann.

Habermas, J. (1987) The theory of communicative action. Volume 2: The critique of functionalist reason, Boston: Beacon Press.

Hamilton, C. (2015) 'Getting the Anthropocene so wrong' The Anthropocene Review 2(2) 102-7

Hamilton, C. and Grinevald, J. (2015) 'Was the Anthropocene anticipated?', The Anthropocene Review 2 (1): 59-72.

Heidegger, M. (1993) Basic writings, London: Routledge.

Honneth, A. and Joas, H. (1988) Social action and human nature, Cambridge: Cambridge University Press.

Jonas, H. (1963) The Gnostic religion. The message of the alien god and the beginnings of Christianity, Boston: Beacon Press.

Jonas, H. (1984) The imperative of responsibility. In search of an ethics for the technological age, Chicago: The University of Chicago Press.

Jonas, H. (2001) The phenomenon of life. Towards a philosophical biology, Evanston: Northwestern University Press.

Latour, B. (1993) We have never been moderns, Cambridge, Mass.: Harvard University Press.

Latour, B. (2013) An enquiry into modes of existence. An anthropology of the moderns, Cambridge, Mass.: Harvard University Press.

Levi-Strauss, C. (1970) The savage mind, Chicago: The University of Chicago Press.

Lewis, S. and Maslin, M. (2015a) 'Defining the Anthropocene', Nature 519: 171-80.

Lewis, S. and Maslin, M. (2015b) 'A transparent framework for defining the Anthropocene Epoch', The Anthropocene Review 2 (2): 128-46.

Lövbrand, E., Beck, E., Chilvers, J., Forsyth, T., Hendrén, J. Hulme, M., Lidskog, R. and Vasileiadou, E. (2015) 'Who speaks for the future of Earth? How critical social science can extend the conversation on the Anthropocene', Global Environmental Change 32: 211-8.

Löwith, K. (1993) Max Weber and Karl Marx, London: Routledge. 
Luhmann, N. (2012) The society of society, Volume. 1, Stanford: Stanford University Press.

Lyotard, J-F. (1984) The postmodern condition, Minnesota: University of Minnesota Press.

Malm, A and Hornborg, A. (2014) 'A geology of mankind? A critique of the Anthropocene narrative', The Anthropocene Review 1(1): 62-59.

Maslin, M. and Lewis, S. (2015) 'Anthropocene: Earth system, geological, philosophical and political paradigm shifts', The Anthropocene Review 2 (2): 108-116.

Morgan, M. (2016) Pragmatic Humanism: On the Nature and Value of Sociological Knowledge, London: Routledge.

Parsons, T. (1978) Action theory and the human condition, New York: The Free Press.

Plessner, H. (1970) Laughing and crying. A study of the limits of human behavior, Evanston: Northwestern University Press.

Robbin, L. and Steffen, W. (2007) 'History for the Anthropocene', History Compass 5 (5): 16941719

Rockström, J. Steffen, W., Noone, K., Persson, A., Chapin, F., Lambin, E., Lenton, T., Scheffer, M., Folke, C., Schellnhuber, H., Nykvist, B., de Wit, C., Hughes, T., van der Leeuw, S., Rodhe, H., Sörlin, D., Snyder, P., Costanza, R., Svedin, U. Falkenmark, M., Karlberg, L., Corell, R., Fabry, V., Hansen, J., Walker, B. Liverman, D., Richardson, K., Crutzen, P. and Foley, J. (2009) 'Planetary Boundaries: Exploring the Safe Operating Space for Humanity' Ecology and Society 14 (2): 32

Sartre, J-P. (2007) Existentialism is a humanism, New Heaven: Yale University Press.

Scheler, M. (2009) The human place in the cosmos, Evanston: Northwestern University Press.

Schelsky, H. (1967). El hombre en la civilización científica y otros ensayos. Buenos Aires: Sur.

Skillington, T. (2015) 'Theorizing the Anthropocene', European Journal of Social Theory 18 (3): 229-35

Sloterdijk, P. (2009) 'Rules for the human zoo: A response to the Letter on Humanism', Environment and Planning D: Society and Space 27: 12-28.

Steffen, W., Broadgate, W., Deutsch, L., Gaffiney, O., and Ludwig, C. (2015) 'The trajectory of the Anthropocene: The great acceleration', The Anthropocene Review 2 (1): 81-98

Steffen, W., Cruzten, P. and McNeill, J. (2007) 'The Anthropocene: Are humans now overwhelming the great forces of nature', Ambio 36 (8): 614-21.

Susen, S. (2007) The foundations of the social. Between critical theory and reflexive sociology, Oxford: Bardwell. 
Trachtenberg, Z. (2015) 'The Anthropocene, ethics and the nature of nature', Telos 172: 38-58.

Voegelin, E. (1962) "World-empire and the unity of mankind", International Affairs 38 (2): 170188.

Zalasiewicz, Z., Williams, M., Smith, A., Barry, T., Coe, L., Brown, P., Brenchley, P., Cantrill, D., Gale, A., Gibbard, P., Gregory, F., Hounslow, M., Kerr, A., Pearson, P., Knox, R., Powell, J., Waters, C., Marshall, J., Oates, M., Rawson, P. and Stone, P. (2008) 'Are we now living in the Anthropocene' GSA Today 18 (2): 4-8

Zalasiewicz, J., Waters, C., Barnosky, D., Cearreta, A., Edgeworth, M., Ellis, E., Gałuszka, A., Gibbard, P., Grinevald, J., Hajdas, I., do Sul, J., Jeandel, C. Leinfelder, R., McNeill, J., Poirier, C. Revkin, A., deB Richter, D., Steffen, W., Summerhayes, C., Syvitski, J., Vidas, D., Wagreich, M., Williams, M., Wolfe, A. (2015) 'Colonization of the Americas, 'Little Ice Age' climate, and bombproduced carbon: Their role in defining the Anthropocene' The Anthropocene Review 2 (2): 117-27.

\section{Acknowledgements}

My thanks to Dave Elder-Vass, Robert Fine, Nikos Sotirakopoulos and Simon Susen for comments on earlier versions of this paper and on the general ideas that inform it.

\section{Notes}

${ }^{1}$ See Crutzen (2002) for what is arguably the intervention that triggered what I treat here as the 'Anthropocene debate'. Also, see Lewis and Maslin (2015a) for the 'pre-history' of the Anthropocene from in $18^{\text {th }}$ and $19^{\text {th }}$ centuries and Robben and Steffen (2007) for developments in the first part of the $20^{\text {th }}$ century. Below I will focus mostly, though not only, on how the Anthtopocene has been discussed in the natural sciences, but it should be noted that this special issue belongs to a growing trend in the social sciences and humanities that tries to respond to the challenges that it poses. See, for instance, recent special issues in Telos (Fall 2015). The recent creation of the journal The Anthropocene Review has the merit of bringing together scholars from different disciplinary traditions.

2 This fits also, for instance, with Ulrich Beck's (1992) argument that contemporary modernity has evolved into a risk society, where risks play the key role of an interface between social processes and natural resources.

${ }^{3}$ See, for instance, Skillington (2015) and Trachtenberg (2015). I have offered a critical account of Latour's ontological claims in Chernilo (2015).

${ }^{4}$ See, most recently, Certini and Scalenghe (2015), Hamilton, C. (2015), Hamilton and Grinevald. (2015), Lewis and Maslin (2015a, 2015b), Steffen et al (2015), Zalasiewicz et at (2015). These articles disagree, among other things, on when did the Anthropocene start, whether there is sufficient empirical evidence to speak of the Anthropocene at all and, if so, what is the kind of empirical evidence being adduced in its favour. 
${ }^{5}$ Because I am interested in exploring its implicit ideas of the human, this piece does not question whether there is such a thing as 'the Anthropocene'. But it must be said that the public plausibility of the Anthropocene builds on the connections it is able to make to political questions about climate change and global warming. Chakrabaty, for instance, just conflates these two debates - the scientific one on the status of the Anthropocene as concept and the political ones on what to do about climate change - but they are different. I am grateful to Nikos Sotirakopoulos for raising this distinction to my attention.

${ }^{6}$ Similar arguments are also available in Crutzen and Steffen (2003) and Steffen et al (2007).

${ }^{7}$ As far as I am aware, the only dimension that still remains exempt from these human alterations is the shape and length of the earth's orbits around the sun.

${ }^{8}$ Lewis and Maslin (2015a), for instance, make reference to Immanuel Wallerstein's world system theory in order to highlight the both global and unequal dynamics of modern capitalism. I have reconstructed the role of universalistic arguments in the rise of classical social theory in Chernilo (2013).

${ }^{9}$ I cannot elaborate on this point in full here, but it is worthy of note that the argument on the great acceleration of the past half a century is very much based on the worldwide impact of industrial technologies. Yet sociologists have mostly claimed that this is precisely the period in which industrialism started to decline: first through post-industrialism and, then informationalism (see Bell 1974 and Castells 1996).

${ }^{10}$ It is somewhat ironic that Anthropocene scholars echo some of the most conventional arguments of early twentieth-century anthropology with regard to human success in the instrumental mastery of the natural world. Compare, for instance, what I have been discussing here with Gordon Childe's (1962) argument in Man makes himself. The main difference lies in their normative tone: whilst early anthropologists were 'humanists' in their belief in progress, Anthropocene scholars are not.

${ }^{11}$ On the connection between anthropological invariants and their sociological realisation, see Honneth and Joas (1988) and Susen (2007: 277-302).

${ }^{12}$ See Chernilo (2017: Ch. 1) for a full account. The question of humanism in social and political thought is experiencing a welcome revival. See, recently, Durkin (2014) and Morgan (2016).

${ }^{13}$ See also Clark (2014).

${ }^{14}$ See, classically, Jürgen Habermas' $(1984,1987)$ distinction between system and lifeworld. I have made a convergent critique of Bourdieu in Chernilo (2014).

${ }^{15}$ Each chapter of my Debating Humanity expands on one of these seven properties (Chernilo 2017). I do not touch on the less flattering dimensions of our species' behaviour (domination, cruelty, lying) because I am interested in the ways in which we can conceptualise such normative ideas as justice, solidarity, and fairness in society. 